\title{
The Triadic Structure of the Human Psychism - between Psychopathology and Theology
}

\author{
Valeriu Gabriel Dimitriu ${ }^{1}$
}

\begin{abstract}
The aim of this work is to present the triontic theory of the normal and pathological human psychism, elaborated by the Romanian psychiatrist Eduard Pamfil, and to highlight its deep connection with the Holy Trinity model of God. The main idea of the work is that mental illness, considered from a wider anthropo-phenomenological perspective, appears as the result of a deficit within interpersonal communication and, in a deeper way, of the lack of communion between human persons. According to Pamfil, the conscious human being is the result of the interaction of its three poles: I (ipseity), You (tui-ty) and He (ille-ity). Pamfil emphasises the inter-ontic nature of the person, its unity and uniqueness. I (ipseity), stands for the "archaic-primitive condition of the person". You (tui-ty) stands for the "alter ego function", the structural pole of personality. He (ille-ity) is the "systemic, axiological pole". Thus, personality is a "mobile crossroad" between I, You and He, which are "moments of phenomenological subjectivity". The psychopathological commentary of mental illness is made for three major clinical entities: neurosis, psychosis, psychopathy.

The above presented theory is closely related to the Orthodox view of human person, who has its spiritual and moral model in the Holy Trinty of God. The modification of the triontic structure of the human person will lead to important changes in the existence of each person ( $\mathrm{I}, \mathrm{You}, \mathrm{He}$ ) within the trinitary relational system, among which mental illness is certainly the most significant.
\end{abstract}

Keywords: triad, ipseity, tuity, illeity, psychopathology, intersubjectivity, Holy Trinity

\footnotetext{
${ }^{1}$ MD Trainee in psychiatry. Department of Psychiatry, University of Helsinki, Finland. Trainee in Daseinsanalytical psychotherapy. Belgian Centre and School of Daseinsanalysis, Bruxelles, Belgium.
} 
PART ONE: The Triontic Theory of Human Person (Pamfil, Ogodescu - 1972)

\section{Introduction}

Being considered a paradigmatic personality of Romanian psychiatry, Professor Eduard Pamfil is the founder of the school of anthropophenomenological psychiatry in Romania. Pamfil emphasized the humanistic character of psychiatry, supporting the "idea of the reconstruction of the individual understood as Being". His major contribution to the Romanian psychiatry is the triontic theory of the human person and, implicitly, the model of triontic psychopathology elaborated together with his closest disciple Simion Doru Ogodescu (Ogodescu, Lăzărescu, 1996; Anghel, 1996). The postulations of this theory are presented in the work Psihologie şi informație [Psychology and Information], whereas three further contributions (Nevrozele [Neuroses], Psihozele [Psychoses], Persoană şi devenire [Person and Becoming]) illustrate the concept of trionticity in relation to three large categories of psychiatric disorders: neuroses, psychoses and psychopathies. It should be kept in mind that the notion of trionticity can be applied both to the normal psychism and disordered psychism (psychopathology). The triontic theory of human person was elaborated between 1972-1976 as a result of over 20 years of clinical work with psychiatric patients, as a result of synthesizing the French Personalist philosophy (E.Mounier), with the theological idea of perichoresis from Eastern Christian thought (developped by the Church Holy Fathers), which we are going to analyse in the second part of this work.

\section{The Human Person - a Triontic Approach}

\subsection{The Concept of Triadic Order (the triad)}

A triontic approach to the human person cannot be completely achieved without the prior presentation of the concept of triadic order (the triad) which is characterized by the following: 
a. first, the three elements (poles) of a reality sector (in our case, the human psychism) must necessarily be irreducible among them.

b. second, the type of the interrelations occurring among the elements must be established. Pamfil and Ogodescu consider that these interconnect in an interchangeable manner (the term must be read as "interpolar recurrent alternation"). Interchangeability does not constitute a simple commutation of the elements, as it takes place with the "remanence of the respective functions" (each pole is enriched permanently by interacting with the others). For example, within the psychic triad I - YOU - HE if I interacts with YOU, the following situation occurs:

$$
\mathrm{I} \leftrightarrow \mathrm{YOU}=\mathrm{I}(\mathrm{you}) \leftrightarrow \mathrm{YOU}(\mathrm{I})
$$

Through the accumulation of these movements, each of the poles of the triad acquires via interchangeability a poly-functional identity (trifunctional), as can be observed in the figure below:
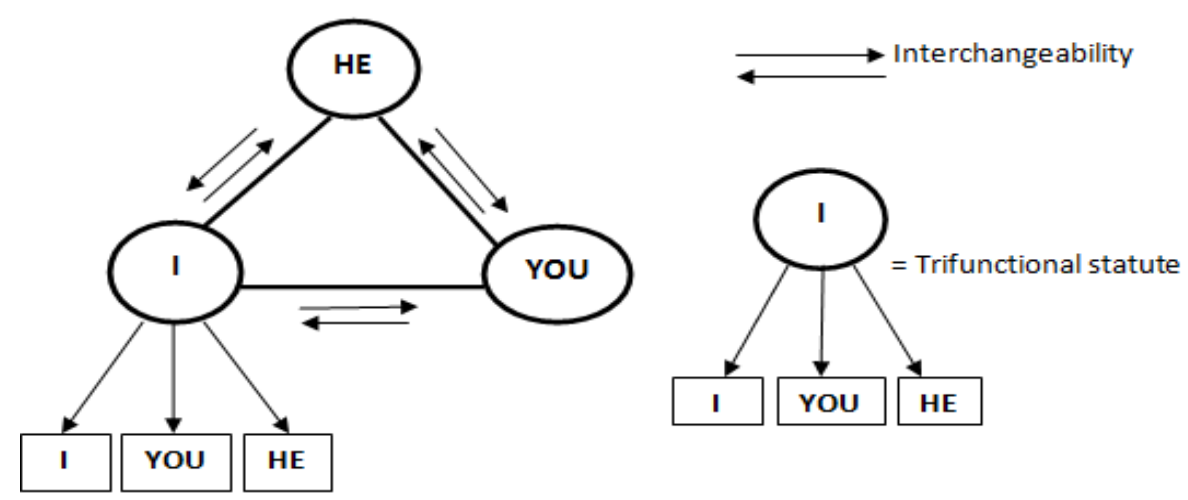

From this diagram one can deduce that interchangeability takes place both ways (clockwise and counterclockwise). Ogodescu distinguishes it from circularity, as it does not leave qualitatively unchanged the elements of the system analysed. It must be highlighted that in the case of interchangeability we speak of a continuous interaction of the elements, which mutually enrich themselves as far as their content is concerned becoming dynamic complexes, 
endowed with the attribute of self-becoming. This becoming is dependent on the overall dynamics of the reality sector concerned. Thus, the interchangeable dynamics takes place simultaneously with the interchangeable dynamics within each pole (Pamfil, Ogodescu, 1973; Ogodescu, 1981).

\subsection{The Triontic Theory of the Human Person}

The triontic model of the human person is presented in a synthetic manner in the work Persoană și devenire [Person and Becoming], which is of crucial importance for the understanding thereof. In Eduard Pamfil's vision (1976), the person represents "the unitary-dynamic organisation of the most representative characteristics of the plenary developed and completed individual". Having meditated for a long time on the human person and its relations to the world, Pamfil coins the (extremely suggestive) term of "personomy", the science of the human person. Another aspect is represented by the functions of liberty, communication and creation with which the human person is endowed. Considering all the ideas above presented, we can define the triontic model (I YOU - HE) as: "a constellation system of three energetically balanced vectors, interchangeable within a continuous sin-ontic movement of total confluence". The trionticity of human nature is given by the three functional, inter-confluent roots, equivalent to as many consciousness functions. We shall present hereafter the postulates of the triontic theory of the person:

a. I, YOU, HE represent "functions of consciousness" and "moments of phenomenological subjectivity".

b. the significance of the three poles: I (ipseity) = the formal pole, "emanant of the psychic energy vector"; YOU (tuity) = the structural (affective) pole, "vector of order and coherence"; HE (illeity) = the systemic (axiological) pole, the "deontic vector". The triontic model aims at investigating the functional 
The Triadic Structure of the Human Psychism between Psychopathology and Theology

capacity of the person at its highest integrative level, of total confluence of the poles. Pamfil underlines the pulsating character of the person: "The poles meet and cannot be individualised by means of a schematic fixation".

c. there is no "topographic area" of I - YOU - HE. The atopism of the triontic unity is given by its dynamic nature ("the person cannot be understood unless it is deduced from phenomena which do not pertain to "psychic organs", but which represent dynamic relations denoting the triple differentiation in which each pole exists as fractional functional individuality only by virtue of the reciprocal interconditionings"). The essential idea is that psychic life cannot be inscribed within any of the poles but only within their interrelation.

d. the anti-enthropic and anti-aleatory character of the person. This refers to the person's capacity of reducing uncertainties and hazard by means of anticipation ("the constellation of the illeity within the shift I - YOU"). Mircea Malița states to this end that "man confronts the highest quantity of randomness among all known systems (...)". The same author considers one way of fighting randomness the fact that man analyses his own condition.

e. the complementarity between the energetic function (I), the antienthropic function (YOU) and the axiological anti-aleatory function (HE).

f. for Eduard Pamfil, I is different from the I found in classic psychology, where the ego is the person itself. Ipseity is only an "archaic-primitive condition", capable of participating in the dynamics of existence only after being completed by the hypostases YOU and HE. Without YOU "the person would not know it exists" (YOU establishes a "maximum of similarity" to I), and without HE ("the optimal of dissimilarity") the person "would not know who it is, would not have a name, would not be noetic, willing, projective, emphatic and moral or creative". The idea that the person communicates exclusively by means of the totality, the interchangeability of the three active centres is therefore essential.

g. the openness of I towards YOU assures the feeling of self unity and continuity. HE ("the appreciative status-enhancing, sanctioning projective pole") is 
linked to the "continuous innovative and prospective dynamism which determines the fact that the responsibility of the axiological engagement should be placed on the firm platform of comprehension".

h. the triontic mechanism of the person may either "compress" (which means an amplification of self-knowledge), or "expand" (the amplification of world knowledge). This is the pulsating character of the person.

i. before the level of the triontic organisation, the person situates itself in an "unstructured general level". This is a "pre-personant" situation where the three poles do not "sin-dynamically" cooperate (they can be individualised). It is what Pamfil calls "the dialectics of "to have'". The coupling of the poles, the closing up of the "personant cycle", followed by the loss of the poles' identity constitute the stages of the "leap into personhood". This is "the dialectics of 'to be'".

j. interonticity is "the last level where the human being may be apprehended in its comprehensiveness of world understanding, communication and love for others". The triontic model of the human person is in fact an interchange between the dialectics of "to be" and "to have", a "continuous methodological reference to a prospective constructivism". (Pamfil, Ogodescu, 1976, Ogodescu, 1981)

\subsection{Ipseity - the Person's Formal Pole}

It must be mentioned from the very beginning that there are no super- or sub-ordination relationships among the three benchmarks of consciousness. Ipseity (I) represents the instinctive level, as well as the basal layer of the affective level (primary emotions area). It designates the aspect of "monontic", of "protopsychism, pre-psychism". At the same time, it refers to the entire aspect of corporality of the human being. It is "the strictly deterministic pole, namely deprived of liberty which institutes the non-probabilistic regime of the human being". It necessarily opens itself towards a YOU. At the basis of ipseity there is a "vital, elementary, fundamental, undifferentiated" energy. Within the triontic unity of psychism a progressive differentiation of the vital energy occurs, followed by 
The Triadic Structure of the Human Psychism between Psychopathology and Theology

"the transfiguration in psychic phenomena". I represents in fact "the condition of the irreducibility to zero of the bipolar sequence I - YOU". Ipseity has as material substrate the brain, designating the "form" of the human psychism. By means of the openness towards an YOU the structural conditions of the person is achieved, I being "the preparatory matrix of the tuity". (Pamfil, Ogodescu, 1973; Pamfil, Ogodescu, 1976)

\subsection{Tuity - the Person's Structural Pole}

YOU represents the replica of I, the person's affective pole. The necessity of having a YOU in front of us constitutes the very need for communication. Eduard Pamfil emphasises the fact that YOU constitutes a "first openness within the person's ontology to which it brings and intensifies the capacity of movement and shaping". He distinguishes a basal affectivity (holothymy), different from the rest of the affects which "ensures the person's coherence and unity". Compared to holothymy, the affects seem a "perceivable, modulated, polarised and communicating" energy. The polar thymic state corresponds to normality and the affective ambivalence is specific to mental illness. The importance of the affective states in relation to the triontic model results from the fact that they "favour the balanced coexistence and the synergetic functioning of the three poles (I, $Y O U, H E) "$. The relationship of otherness to illeity is described by Pamfil in the following observation: "deriving from ipseity from which it borrows the tension and the direction, the affectivity colours illeity as well, which creates in its supreme form the comprehensive system of the emotional states". (Pamfil, Ogodescu, 1973; Pamfil, Ogodescu, 1976)

\subsection{Illeity - the Person's Systemic Pole}

Eduard Pamfil considers ipseity as being "out of time and space", tuity as being „spatial" ("here"), and illeity "temporal". Their simultaneous functioning enables the leap to the plane of the person ("temporal-spatial 
continuity"). In the I-YOU plane a "communication tension" occurs which reaches accomplishment through HE. By means of this pole "the person creates and accomplishes itself as presence and axiological engagement in the world". Pamfil calls it "the very generous root of the human being". (Pamfil, Ogodescu, 1973; Pamfil, Ogodescu, 1976)

It is important to make a difference between the triadic interpersonal model of communication (where I, YOU, HE are personal pronouns) and the interior triadic model of the human person. Pamfil and Ogodescu had at first this interpersonal model of communication and after that they "transferred", „interiorized” the three poles within a single human being. In this second case I, YOU and HE became functions of consciousness (moments of phenomenological subjectivity) (Pamfil, Ogodescu, 1976; Ogodescu, 1981)

\section{The Triontic Psychopathology}

After having analysed the triontic model of the human person and each of its elements (I, YOU, HE) separately, let us now explain the model of triontic psychopathology, for which Pamfil and Ogodescu borrowed the mathematical apparatus of the theory of games. The triad is a "system model in which three rational elements interact, capable of analysing the different alternatives and making decisions intended to be optimal from certain points of view". The parameters which could be evaluated within the triad are the surprise, the organisation, the recognition and the prediction which result from the interaction of the respective elements. (Pamfil, Ogodescu, 1976). We are interested in the organisation degree of the triadic model knowing that the more structured a system is, the clearer becomes the definition of the behaviour of the assembly despite the undetermined behaviour of the elements.

When do we face a maximal organisation degree? When we face a system with three interdependent elements. The relationships among the 
The Triadic Structure of the Human Psychism between Psychopathology and Theology

elements may be of coalition or conflict. We can distinguish three types of coalition:

1. Ordinary coalition - each player plays for him/herself. In this case there are three subgroups, each containing one player: (1), (2), (3)

2. Classical coalition - two players join forces while the third remains alone: $(1,2) \times(3)$

3. Total coalition - all three players join forces choosing together by cooperation the strategies to follow for their common interest: $(1,2,3)$.

Total coalition offers a model that presents the highest interdependence and coherence possible and which, converted in the terminology of psychopathology, could represent the model of the normal person.

Considering the triad as a system, four types of subsystems can be formulated:

Model I (1, 2, 3) (1) (2) (3)

This is the triadic model with the maximal degree of organization.

Model II $(1,2,3)(1,2) \times(3)$

Model III $(1,2,3)(1,3) \times(2)$

Model IV $(1,2,3)(1) \times(2,3)$

Therefore, it can be noticed that the organization of a system with three elements (model I) is higher than that of a system with two subsystems (models II, III, IV). Comparing these models of triadic nature to the psychopathological reality, Pamfil and Ogodescu suggest in an expressive manner the disorganisation engendered by the psychic disease in a person's coherence and unity (1976).

Pamfil and Ogodescu consider that model II: $(1,2) \times(3)$ is characteristic to psychopathy, denoting the unbalancing coexistence of I - YOU and HE. 
Model III: $(1,3) \times(2)$ illustrates a modification in the function of alter-ego, the confliction tension between (I - HE) and YOU, and is defining for the neurotic suffering.

Model IV: (1) $\times(2,3)$ illustrates the antagonistic tension between ipseity (I) and the other poles, and is defining for the psychotic suffering.

It is essential to highlight that, whereas the normal person is triontically defined (structured), the mentally ill person is diadically structured. The reason is that mental illness can be defined as a conflict between two subsystems in triontic terms.

\section{Neurosis - a Triontic Approach}

Also an advocate of structuralism, Eduard Pamfil analyses the problematics of neuroses from a structuralist perspective, considering that the patient presents a structural shortcoming, a cleavage at the I - YOU level while HE (the values pole) is only a "surrogate". In other words, the neurotic disorganisation occurs in the pre-person which means a loss of the triadic balance I - YOU - HE. As we mentioned above, the perfect model of the triad is precisely the normal human being, noted in the language of the games theory as follows:(I, YOU, HE) (I) (YOU) (HE)representing the highest organisation and cohesive interdependence degree which could be defined through a triad. Compared to the model of the normal person, the neurotic person receives by way of schematisation the following psychopathological model built on two conflicting subsystems:

$$
(\mathrm{I}, \mathrm{YOU}, \mathrm{HE}) \quad(\mathrm{I}, \mathrm{HE}) \times(\mathrm{YOU}) \quad(\mathrm{I})(\mathrm{HE})
$$

We can see that in the case of the subsystem (I, HE) in conflict with (YOU), the organisation degree is lower compared to the triadic model of normality. Neurosis means, therefore, the slant and the disorganisation of the triadic structure by means of this conflict which translates into "inauthenticity, negative energetic balance and axiological disengagement". The triontic model of 
The Triadic Structure of the Human Psychism between Psychopathology and Theology

neuroses, the synthesis between the medical and the anthropological perspective comprises two directions of analysis: the first approaches neurosis as a statute, as the structure of the person (the synchronic perspective), whereas the second examines neurosis as dynamics and evolution (the diachronic perspective). In the terms of the triontic theory, the above mentioned ideas may be reformulated as follows: "when the neurotic has his YOU (tuity) offered in the natural generosity of communication, he or she does not recognise it; and when he or she does not have it, he or she looks for it in a painful manner". The patient does not feel completely represented by his or her actions. In a metaphorical but suggestive phrasing, Eduard Pamfil observes: "neuroses arise among foggy mirrors where the silhouette of ipseity (I) does not get decoded. The blurry mirror of the otherness (YOU) does not offer the neurotic the secret of his or her own image (alterego) and the balance of the recurrent fall in him/herself". Thus, the loss of the triontic balance occurs, translated into an inconsistently structured and permanently threatened profile (Pamfil, Ogodescu, 1974)

\section{Psychosis - A Triontic Approach}

From the perspective of the triontic theory, psychosis represents a "negative reply" of all psychic functions. By its ambivalence, a real "evolutionary negation," the patient crashes from a world of values and significations in a world "with no dimensions, no horizon and without the fundamental scheme of the person - external world symbiosis". Starting from the games theory, Pamfil and Ogodescu elaborated a triontic model of the normal person and, in parallel, a model of psychoses. The triontic model with the maximal organisation degree (I) defines the normal person. As stated above, the three poles (I, YOU, HE) are in a total coalition:

Model (I) (I, YOU, HE) (I) (YOU) (HE)

Model (II) (I, YOU, HE) (I) x (YOU, HE)

Model (II) is characteristic to psychoses and illustrates the antagonistic 
tension (conflict) between ipseity (I) and the other two poles (YOU, HE). Compared, these two models indicate the disorganisation provoked by insanity in the human person, an idea suggested by the fact that the organisation of a system with two conflictual elements (I) x (YOU, HE) is lower than in the case of the triontic one (I, YOU, HE). By way of the tension among the triontic poles, the psychotic patient loses in the end the YOU (the otherness) in the dissociative process and the HE (illeity) also in the delusional "invasion" defining himself as an "anti-person, as an inwardly retraction formula, progressively devastating the psychic life". The psychotic suffering is basally situated in the architecture of the psychism and more specifically at the level of the person's form (of the I). At the origin of psychosis we always find the lack of human resonance, of openness towards otherness (YOU). The blocking of the I - YOU split that instates the only form of identity possible of the human person explains the existence of the psychotic "suspended in the primordial chaos of endogenesis". (Pamfil, Ogodescu, 1976)

\section{Psychopathy - A Triontic Approach}

In the case of the psychopathic person, the disorganisation presents the following formalised model: (I, YOU) $\times(\mathrm{HE})$

We can notice that the subsystem (I, YOU) is in a contradictory tension in relation to (HE). Psychopathy represents the refusal of the supreme human value which is "the prospective investigation of the existence, the refusal of the destiny-related interrogation".

As we mentioned above, neurosis represents "the disappearance of the axiological self-determination", as it presents an alter-ego deficit (YOU). The psychopath unscrupulously chooses his or her YOU as it is like a "perfect mirror no one can approach". He or she discovers him/herself "with the same indifference a lion looks at its image reflected in the spring from which it drinks". While for the normal person the YOU means love and communication, for the psychopathic person 
The Triadic Structure of the Human Psychism between Psychopathology and Theology

it's only a "neuter and icy reference". The psychopathic person lives the dissociation between the "logic-comprehensive development and the interaction capacity". The axiological level is not only a concept but also an attitude in which the "notional is only the component by means of which the act couples in normality". With these ideas, Pamfil infers the definition of the psychic disease considered globally. He emphasises that any disorganisation of the triontic structure signifies an axiological disengagement and, therefore, "the cutting-out of the moral dimension of the human being". Psychopathy does not mean, however, the negation of the ethic but a non-harmonic coexistence between moral and instinctive. We emphasize that for the psychopathic person, the loss of moral dimension (the HE, which we defined as "axiological pole") remains its essential feature (Pamfil, Ogodescu, 1976)

\section{PART TWO: Theological Perspectives of the Triontic Theory of Human Person}

\section{General Remarks on Perichoresis}

After having presented the triontic theory of human person as it was conceived by Pamfil and Ogodescu, let us now extend our analysis by making a parallel between this theory and the idea of "perichoresis" that is, the relationship between each Person of God (Father, Son, Holy Spirit). The etymology of this word: peri "around" and chorein "to make room for", "go forward", ,contain".

The term was first used by Church Holy Fathers. It first appeared in the works of St Maximus the Confessor, but the related verb perichoreo is found earlier at St Gregory of Nazianzus' works. St Gregory of Nazianzus highlighted the relationship between the divine and the human nature of Jesus Christ as John of Damascus did, but he also extended it to the "interpenetration” of the 3 Persons of the Holy Trinity. As it is known, the view that the Son was 'of the essence of the Father, God of God...very God of very God' was formally ratified 
at the First Council of Nicaea in 325 CE. The Holy Spirit was included at the First Council of Constantinopole (381 CE), where the relationship between the Father, Son and Holy Spirit as one substance (ousia) and three co-equal Persons (hypostasis) , was formally ratified.

As far as dogmatic and logical aspects are concerned, an important contribution to the Romanian Christian Orthodox literature brought Father Calinic Botoșăneanul. In his work Logica Trinității [The Logic of Trinity] (2005) he analyses the concept of perichoresis by applying both natural and dialectic logic, which facilitates a better understanding of the paradoxical logical structure of the Trinitary dogma. We are not going to develop in detail these issues concerning the dogmas and logic of Holy Trinity in our work. However, it is important to highlight some facts about the relation between ousia and hypostasis. As a general dogma, it is known that God is One being, but Three Persons. Father C. Botoșăneanul analyses this dogma: "Father, Son and Holy Spirit are names which are not in relation to the identical and common divine substance, but to the relations of personal origin and communion. Although communion is personal, it is beyond any objectivity or subjectivity. The relations of unity and love, which represent the involvement of the Holy Spirit within the life of two or more He encounters, are essential to the Trinity, as it expresses the very interpersonal existence of humanity. The being of God subsists as trinity of Persons or Hypostases, and within the Trinity there is an identity of kind, will and achievement. So, the logicity of Trinity must be analysed not within the limited logic of the heresiarchs, but within the relation between ousia and hypostasis (...)". He continues by pointing out that "from the human logic's point of view, the term hypostasis is included, as far as form is concerned, in the term of ousia, but as far as content is concerned, the notion of hypostasis includes the features of the ousia". The paradox One as being and Three as persons indicates the fact that "antinomies can have solutions beyond human logic". (Father C.Botoșăneanul, 2005). In the same above mentioned work, it is mentioned that "any dogma is an antinomy for the logical possibilities of the human intellect, but a transfigured one, that is antinomies which - although implying for us humans something antilogical - belong 
The Triadic Structure of the Human Psychism between Psychopathology and Theology

(...) to a category of unachievable solutions for the human mind and its logical functions. The avoidance of this paradoxical situation can be realized - according to the Romanian philosopher Lucian Blaga - by approaching the Christian dogma from a transcendental perspective, where the logical and the concreteness are absent, and the antilogical is admitted and receives solutions through Revelation, beyond human intellect" (Father C. Botoșăneanul, 2005).

\section{From Interpersonal Communication to Communion}

An attentive comparison between the triontic theory of Pamfil and the Holy Trinity model of God would show us the path from interpersonal communication to communion between persons. Related to this topic, a major contribution was made by Father and Orthodox theology professor Dumitru Staniloae, who analysed the concepts of "perichoresis" and "communion" in the Romanian Christian Orthodox literature $(1993,2010,2013)$. As we know, the human person has its spiritual and moral model in the Holy Trinity of God. If interpersonal communication is formal and exterior, communion is closely related to affectivity and interiority, it is the expression of a "mutual interiority", as the French philosopher Gabriel Madinier stated (Madinier, 1947).

Communion involves a deep affective participation of the person who is in mutual relation with another person. Within the communion "I" see/find myself in "YOU”, in another "ME", just like "YOU" see yourself in "ME", who is another "I" of "YOURS". The "I"-s of the two persons do not lose their individuality, they only converge within the intimacy of Love. Father Staniloae brings a very important argument which emphasizes the value and significance of the communion between persons that is, the compulsory intervention of a third person (HE), to whom we (I and YOU) refer in the communion relation. $\mathrm{HE}$ is the condition that guarantees the possibility of communion, the model accepted by both I and YOU who have the same affective attitude towards HIM (third person). The love between two persons involves the love for a third who is always invoked and thus "presentified" within the relation of communion. I 
see myself in YOU. YOU see yourself in ME, because both I and YOU see each other in HIM (trionticity). This is the triadic ontological structure of the human person.

When it comes to the Holy Trinity, the communion of the three Persons involves the transmission of the ontological features of Each. This fact is argued by the mereological interpretation of Holy Trinity. However, Father C. Botoșăneanul (2005) points out that „unlike Lesniewski, the founder of mereology, (...) Father Staniloae uses the term of partitive logic (whole - part) to demonstrate that a feature like deity belongs both to the whole (Trinity) and to Each Person. One and the same divine nature subsists in an unborn way within Father, in a born way within Son and in a derived way within Holy Spirit. In other words, within Holy Trinity there are features which are being transmited from whole to part (deity, eternity etc)". St Gregory the Theologist talks about Holy Trinity as moving and not moving at the same time ("static movement and moving state"). In the same manner, inspired by the Christian dogma, the Romanian philosopher Constantin Noica interprets the Persons of Holy Trinity as holomers, by stating that Father, Son and Holy Spirit are consubstantial and signify "a division without separation of their whole" (Father C. Botoșăneanul 2005).

\section{Trionticity and Perichoresis: on Trinitary Intersubjectivity}

According to Father Staniloae (2010), God is "Pure Subject or Trinity of Pure Subjects". All His divine essence is subjectified. Neither of the three Subjects sees anything as object in the Others' Persons and nor in Himself. That is why He experiences the Others as Pure Subjects and also Himself as Pure Subject. If within the three Persons were any feature of object, this would diminish Their perfect openness towards the other two Subjects, They would not exist as three interior subjective consciousnesses. Thus there would be no communion between Them. As Father Staniloae continues, "the perfect communion is possible only among the persons who are and become transparent as pure subjects". The more they exist as subjects, the closer their interrelations become, 
also a higher degree of intersubjectivity is reached by a mutual intentional conpenetration. The pure nature of the Holy Subjects involves a perfect intersubjectivity of Them (the highest degree of intersubjectivity). That is why we talk about a unique God and three "II"-s (Subjects). The three Subjects do not become separate from One Another. Thus the subjectivity of neither of the Subjects does not diminish, but it widens, by comprising the Others too. Each of the Subjects lives (experiences) the ways of experiencing the Holy Being, not as His but as Their.

As Father Staniloae says, "the striving (...) of the human person to be a simple unity and at the same time to comprise everything and to be in an ontologico-dialogical relation with other persons, that is to have them interiorized as subjects, is a reality perfectly achieved within God (...), otherwise (...) the dialogical relations of human persons could not be explained".

According to Father Staniloae and to the Orthodox Church Holy Fathers, each Subject within God is and comprises everything, but His genuine happiness resides in the fact that each "I" (Subject, Person) who is everything includes the Other Subjects who are also everything, Each of Them being everything in this mutual relation. These Subjects do not encounter from exterior, like human subjects do, but from the interior. The Holy Unity of God is in fact a perpetual ontological dialogue in three. Neither of the participants at the dialogue brings any content from the exterior.

\section{The Importance of the Third}

Concerning communion, Father Staniloae (1993, 2010, 2013) points out that "communion within two persons is limited (...). (...) It does not open the whole horizon involved in existence. The two do not always open towards each other, they also become estranged, closed. The other becomes not only a window for me, but also a wall. The two cannot live only by themselves. They need to be aware of a horizon which goes beyond them, but in relation to both of them. And this horizon cannot consist of an object or of a world of objects. This does not take them out of the monotony of a narrow 
view or from a loneliness in two. Only the third subject takes them out from their continuous loneliness in two, only the third subject who can himself be a partner of communion and does not stay passive in front of them, like an object". Only through the third (that is the HE from the triontic theory of Pamfil), the love of two persons become generous, able to spread towards subjects from the external world. Thus, the name of Holy Spirit is often associated with love within God. Only because there is a third one (a HE), "the two can become simultaneously one, not only through the reciprocity of their love, but also through their common forgetfulness in relation to the third.(...) The third can be considered as the "object", the horizon which assures the two their own objectivity, because the third prevents them from intermingling in an indistinct unity, produced by the exclusivism of their love, deriving from the belief of each that there is nothing worth loving but the other".

Father Staniloae suggests that we could imagine a subject without a relation like a spot, the relation between two subjects like a line linking two spots, their relation with a third one like a surface which includes everything in its interiority, namely a triangle. This intentionality is achieved within the Holy Trinitary communion. Commenting on the ontology of love Father Staniloae wrote about in his works, Father C. Botoșăneanul says: „In the works of Father Staniloae we encounter an ontology of love based on: <God is love> (I John 4, 16), where the anthropological premises are subordinated to a cosmology and theology of love. This ontology of love provides the basis of a certain view of the world and is closely related to epistemology, ethics and axiology, to rationality and mystery, which mutually organise within the ultimate reality and according to its specific features".

\section{Conclusions}

To conclude, we can make a few essential remarks on triontics taking into account the above analyzed issues:

The triontic theory of human person provides a unitary view of human psychism. 
The Triadic Structure of the Human Psychism between Psychopathology and Theology

The analysis of the trionticity can be extended to an analysis of the perichoresis concept developped by the Church Fathers.

Mental illness can be interpreted as an alteration of the triadic structure of the human person; the mentally ill person, regardless of the illness' type, appears as "diadically reduced" and beyond the triontic situation (cannot authentically communicate with the others).

Mental illness can be interpreted as a failure of interpersonal communication and, in a deeper way, as a failure of communion between persons.

All in all, we can consider that the triadic ontological structure of the human psychism is an equivalent of the trinitary model of God (Holy Trinity) and mental illness appears to be, in its deepest meaning, an alteration of God's image within the human person.

\section{References}

Anghel, I.N. (1996) Cartea cu Pamfil. Editura Amarcord, Timiş̧oara.

Botoșăneanul, C. (2005) Logica Trinității. Editura GEDO, Cluj-Napoca.

Madinier, G. (1947) Conscience et amour. Essai sur le <Nous>, PUF, Paris.

Ogodescu, D. (1981) Persoană şi lume. Ordinea triadică în gândirea contemporană, Editura Albatros, București.

Ogodescu D., \& Lăzărescu M. (1996) Eduard Pamfil sau jocul de-a geniul, Editura Helicon, Timişoara, 1996.

Ogodescu, D. (1981) Persoană şi cunoaştere. Editura Politică, București.

Pamfil, E., \& Ogodescu, D. (1973) Psihologie şi informație. Editura Ştiințifică, București. 
Pamfil, E., \& Ogodescu, D. (1974) Nevrozele, Editura Facla, Timişoara.

Pamfil, E., Ogodescu, D. (1976) Psihozele, Editura Facla, Timişoara.

Pamfil, E., Ogodescu, D. (1976) Persoană şi devenire, Editura ştiințifică şi enciclopedică, București.

Stăniloae, D. (2010) Teologia dogmatică ortodoxă. vol.1, Editura Institutului Biblic și de Misiune Ortodoxă, București.

Stăniloae, D. (2013) Chipul nemuritor al lui Dumnezeu. Editura Basilica a Patriarhiei Române, București.

Stăniloae, D. (2013) Iisus Hristos sau restaurarea omului. Editura Basilica a Patriarhiei Române, București.

Stăniloae, D. (1993) Sfânta Treime sau la început a fost iubirea. E.I.B.M.B.O.R., București. 